\title{
LOCAL INCOME TAXATION- A 1953 ADDENDUM
}

Jefferson B. Fordham $\dagger$

The purpose of this paper is to supplement a rather extended discussion of local income taxation which appeared in $1950 .^{1}$ During the interval there have been a number of legal developments of some interest.

While there is no immediate concern with statistical coverage, it is appropriate to state that there has been no conspicuous increase in the employment of this form of taxation. It was put forward recently in New York City as a likely means of meeting revenue needs, but was not embraced by Council.

Pennsylvania remains far in the van in terms of the number of local units levying such a tax. It is reported by the State Department of Internal Affairs that, as of April 1, 1953, there were 286 local units levying income taxes under the amended Home Rule Tax Act of 1947, ${ }^{2}$ in addition to Philadelphia, whose authority is derived from the Sterling Act of 1932.3 Even so, the total is only eight per cent of the 3563 units eligible to impose such a tax. ${ }^{4}$ The revenue involved is not great. Philadelphia, in 1952, reaped the substantial total of $\$ 45,000,000$ plus; all the rest collect, in the aggregate, less than a third as much. ${ }^{5}$

Ohio continues to be the second most active local income tax state. All Ohio municipalities have constitutional home rule power to impose such a levy, but only nine have done so. ${ }^{6}$

$\dagger$ Dean of the Law School, The University of Pennsylvania.

1. Fordham \& Mallison, Local Income Taxation, 10 OHIo ST. L.J. 217 (1950).

2. PA. Stat. ANn. tit. 53, $\$ 2015.1$ et seq. (Purdon Supp. 1952).

3. Pa. Stat. AnN. tit. 53, $\S 4613$ (Purdon Supp. 1952). In a pending case involving a mercantile license tax the city is contending that the power to tax derives from an Act of April 29, 1844, P.L. 486, the codification and reenactment of which in 1933 (Act of May 22, 1933, P.L. 853) superseded the intervening Sterling Act. The contention has been rejected in common pleas court. Philadelphia Saving Fund Society v. City of Philadelphia, 128 LEGal INTELLIGENCER 511, 515 (April 23, 1953).

4. Taxes Levied Under Act 481-Receipts, New Taxes, Rate Changes, tables 1 and 2 (Bureau of Municipal Affairs, Pennsylvania Department of Internal Affairs, April 1, 1953). It is to be borne in mind that the 1502 second class townships do not have power to levy income taxes under the act.

5. Id., table 3 .

6. To the list of six cities set out in Fordham \& Mallison, supra note 1, at 223, are to be added three smaller municipalities: Campbell, Lancaster and Struthers. 
A test of home rule power to levy an income tax recently went awry in Saginaw, Michigan. ${ }^{7}$ The City of Saginaw has a home rule charter. In 1951 a proposed amendment, which authorized an "excise" tax on earnings, was submitted to the electors. The proposed amendment contained further provisions which related to a change in property tax limitations and the disposition of the "excise" tax proceeds. A favorable vote was had. Persons who would be prospective "excise" taxpayers and one ad valorem taxpayer attacked the amendment in an injunction suit. There was much interest in the question of power of a Michigan municipality to provide in this way for an income tax; but the decision, which was adverse to the amendment, was rested entirely on another ground of attack, namely, that several subjects were combined in a proposed charter amendment in violation of a single-subject requirement of the home rule enabling act.

\section{State PreËmption}

In Ohio there is a judicially fashioned doctrine that the levy of a state tax so far preëmpts the field as to oust or preclude like municipal taxation even though the tax statute makes no reference to local taxation. ${ }^{8}$ In Pennsylvania, state preëmption is ordained by statute. ${ }^{9}$ The application of the preemption rule is a matter of no little difficulty. The courts of both states have had their troubles with it. In neither state has there been adherence to subject of taxation as the test. On occasion, as illustrated in the earlier paper, tax measure and economic incidence have been looked to.

The principal development on this front is taking place right now in Philadelphia. There is a case now pending in the Supreme Court of Pennsylvania which does not involve a local income tax but bears directly upon the subject of preëmption. In view of the pendency of this case, present treatment is expository.

It will be recalled that the Supreme Court of Pennsylvania determined in 1950 that Philadelphia could not apply its local income tax to corporate dividends received by individuals nor to corporations, ${ }^{10}$ since, as to both individual and corporation taxation, the state franchise

7. House v. City of Saginaw, 334 Mich. 241, 54 N.W.2d 314 (1952).

8. The Ohio doctrine was examined critically and at some length in Fordham \& Mallinson, supra note 1 , at 224 et seq. (1950). There have been no intervening developments worthy of comment. The doctrine was applied in Youngstown Municipal Ry. v. City of Youngstown, 154 Ohio St. 311, 95 N.E.2d 585 (1950), to invalidate a municipal excise measured by gross revenue, on an urban transit company, in view of an existing state excise measured by gross revenue.

9. PA. Stat. Ann. tit. 53, $\$ 4613$ (Purdon Supp. 1952) (Sterling Act); PA. Stat. Ann. tit. 53, §2015.1A (Purdon Supp. 1952) (Home Rule Tax Act).

10. Murray v. Philadelphia, 364 Pa. 157, 71 A.2d 280 (1950). 
tax and excise tax measured by corporate net income attributable to Pennsylvania preempted the field as to foreign corporations and the state capital stock tax and excise tax measured by corporate net income effected preëmption with respect to domestic corporations.

Previously, the court had determined that a Pittsburgh mercantile license tax, the measure of which was gross income, was not barred by state levies on domestic and foreign corporations. ${ }^{11}$ The Pittsburgh tax was confined in its application to wholesale and retail merchants, to operators of restaurants, and to brokers. With respect to the corporate net income tax, the court observed that the state levy was, in substance, imposed on property, whereas the Pittsburgh tax was imposed on gross volume of business. One might interpolate the observation that the stated subject of the Pittsburgh tax was the privilege of engaging in a mercantile business; gross volume of business was the measure of the levy. The court concluded that the franchise tax on foreign corporations was not preëmptive, since both the subject and the measure of that tax differed from the subject and the measure of the city tax. The state tax, it was said, is imposed on the privilege of doing business in the corporate form while the municipal levy is imposed on doing a mercantile business in any form; and the state tax is measured by the value of the corporate property in the state, whereas the municipal impost is measured by the gross volume of business.

The recently enacted Philadelphia mercantile license tax is broader in application than the Pittsburgh impost. The ordinance makes every person desiring to engage in or attempting to engage in any business subject to the tax, and business is defined in $\S 1$ (e) to mean "the carrying on or exercising for gain or profit within the City of Philadelphia of any trade, business, profession, or vocation, or making sales to persons within the City of Philadelphia, or any manufacturing, commercial or financial activity, service or business, including but not limited to, manufacturers, brokers, wholesale dealers and wholesale vendors, retail dealers and retail vendors."

The pending case or, more accurately cases, are equity proceedings initiated in the court of common pleas to enjoin the enforcement of the tax against various corporate plaintiffs and against investment and security dealers doing business in Philadelphia. A class suit was brought in the interests of the investment and security dealers.

The corporate plaintiffs in the Philadelphia case consist of saving fund societies, a domestic and a foreign corporation engaged in the (1948).

11. Federal Drug Company v. City of Pittsburgh, $358 \mathrm{~Pa} .454,57$ A.2d 849 
business of making small loans and consumer discount loans, respectively, and a corporation engaged in the manufacture and sale of bakery products. All of the corporate plaintiffs pay state taxes measured by net income as well as other taxes or fees. In common pleas the tax was held invalid as applied to those plaintiffs. ${ }^{12}$

The court relied heavily upon the two Murray cases, the 1950 Supreme Court decisions previously mentioned. ${ }^{13}$ It read the cases to mean that the preemption provision of the statute was designed to protect state sources of revenue by avoiding double taxation. So far as preëmption was concerned, the court could see no difference between a tax upon dividends in the hands of a shareholder of a corporation which pays a net income and capital stock tax and a local tax upon gross income of a corporation which pays a tax on net income to the state. It regarded both as instances of double taxation of the same subject. The Pittsburgh mercantile license tax case was distinguished on the ground that the Pittsburgh levy was a genuine mercantile license tax, confined to those engaged as merchants or in mercantile service activities, whereas the Philadelphia tax reaches business activity generally. It may be added that a corporation engaged in a mercantile business would, of course, be subject to the state tax measured by corporate income and to the state franchise tax or the state capital stock tax, depending upon its status as a foreign or domestic corporation.

It is of interest in this connection that the Court of Quarter Sessions of Erie County ruled in 1950 that a municipal excise tax of one-tenth of one per cent of the gross receipts from manufacturing activities could not be collected from corporations; the state corporate net income tax and the capital stock tax were said to bar the way. ${ }^{14}$ The court reasoned that both the local and the state taxes were imposed on property and, in any event, that there was double taxation on the privilege of doing business.

\section{Corporations}

Reference has already been made to the Pennsylvania situation under the heading of preëmption. Local units in Pennsylvania simply have not been able to reach corporations through the income tax.

In Ohio it would appear that the way is open to what the courts regard as non-discriminatory local taxation of corporate income. In

12. Philadelphia Saving Fund Society v. City of Philadelphia, 128 LEgAL INTELLIGENCER 511 (Âpril 23, 1953).

13. Supra note 10.

14. In re Erie Gross Receipts Tax, 73 Pa. D. \& C. 313 (1950). 
two cases arising in the Youngstown area, corporations have succeeded in their attacks upon local income levies regarded as discriminatory. The City of Campbell levied an income tax of seven-tenths of one per cent per annum upon net profits of corporations earned as a result of business activities conducted in the city, but levied no income tax upon individuals. The Youngstown income tax ordinance taxed individual income at the rate of three-tenths of one per cent per annum and corporate income at the rate of one per cent per annum. The Court of Appeals concluded that both ordinances denied equal protection of the laws under the pertinent provisions of the state and federal constitutions. ${ }^{15}$ In concluding that there was no reasonable basis for the classification, the court relied upon the well-known Quaker City Cab Company case. ${ }^{16}$

Since a corporation derives its privilege of doing business in the corporate form from the state and not from any local unit of government, it is undoubtedly easier to sustain a rate classification in a state income tax law, which is adverse to corporations, than such classification in a local income tax ordinance. At the same time, even though corporate advantages do not derive from local government, they yet are enjoyed on the local scene, just as they may be on a national scale so far as federal income taxation is concerned. It is true that the Quaker City Cab case has not been overruled, but it is difficult to believe that the Youngstown ordinance, for example, would have been in serious jeopardy in a federal court. There is nothing more commonplace than separate classification of individuals and corporations for tax purposes. ${ }^{17}$ It is common, moreover, to subject businesses conducted in the corporate form to heavier taxation than similar businesses operated by individuals. In the cab case there was the factor of singling out corporations in one type of business, transportation. That presented competitive considerations. The Ohio local taxes, however, applied to corporations generally.

Suppose the Ohio fact patterns were reversed. Would not the court be forced to say that to tax the individual and not a corporation or to impose a higher rate on the individual would deny him equal protection? That is the logic of the Ohio decision. It strengthens doubts as to the soundness of a decision which rejects an individualcorporation classification for tax purposes.

In Pennsylvania, state preemption bars the way so far as corporate income is concerned. Were there otherwise substance to the equal

15. Youngstown Sheet and Tube Co. v. City of Youngstown and Youngstown Sheet and Tube Co. v. City of Campbel1, 91 Ohio App. 431, 108 N.E.2d 571 (1951).

16. Quaker City Cab Co. v. Pennsylvania, 277 U.S. 389 (1928).

17. See the authorities cited in the dissenting opinion of Mr. Justice Brandeis in the Quaker City $C a b$ case, id. at 403. 
protection objection, would the factor of preemption obviate it? Does it necessarily follow that because the state itself does not permit the local unit to tax evenhandedly, the equal protection question is silenced? That hardly suggests the answer, since the state is bound by the equal protection clause. More compelling is the contention that the local tax does not have to be regarded for equal protection purposes independently of the state tax system.

\section{Persons and Income Subject to the Tax}

Perhaps the most interesting development in this branch of the subject has been the effort to gain statutory exemption of nonresidents from the Philadelphia income tax. It is estimated that such a change would cost the city $\$ 10,000,000$ in annual revenue. On June 11 , 1953, the Senate bill embodying the proposal was defeated in the lower house of the General Assembly. The writer, who is a "daylight citizen" of Philadelphia, applauds this action.

One of the chief virtues of the local income tax (and it has its policy weaknesses too) is that it provides an effective means of getting the suburbanite to contribute to the support of the central city government, the protection, facilities and services of which he enjoys. In simple terms of paying something for services rendered, it is only just that the daylight citizen pay municipal taxes in this or some other form. He should have, moreover, a broad interest as a citizen of the larger community in the strength and stability of the urban hub.

It is only fair to add that Philadelphia does occupy a favored position in the Pennsylvania framework. The Home Rule Tax Act expressly provides that a payment of a tax to a local subdivision, pursuant to an ordinance or resolution adopted prior to the effective date of that Act shall be allowed as a credit against any like tax on income imposed by any other political subdivision under the authority of the Act. ${ }^{18}$ This means that Philadelphia, which had an income tax long before the Home Rule Tax Act was adopted, does not have to take into account the income taxes of neighboring local units. Even as to residents of those units who work in Philadelphia it is the non-Philadelphia unit which must allow the credit. What makes this fact the more significant is that the Philadelphia levy is one and onefourth per cent, whereas the aggregate levy which may be imposed under the Home Rule Tax Act, even by overlapping units in the aggregate, is one per cent. ${ }^{19}$

18. PA. Stat. ANn. tit. 53, $\$ 2015.5$ (Purdon Supp. 1952).

19. Pa. Stat. Ans. tit. 53, $\$ 2015.1$ (E) (c) (Purdon Supp. 1952). 
The status of persons in active military service with respect to local taxation has been brought into the foreground by a recent decision of the Supreme Court of the United States. The Soldiers and Sailors Civil Relief Act provides that for purposes of state and local taxation of a person, his property or income, a person does not lose his residence or domicile in a state or local unit solely by reason of absence in compliance with military orders, nor does he acquire a residence or domicile in any other state by reason of such absence. ${ }^{20}$ The Act expressly provides that personal property shall not be deemed to be located or present in or to have a taxable situs at the place of duty station. In the case to which reference has been made the Court held that the statute effectively immunized from local property taxation the household goods of an air force officer from Louisiana, who was on duty station in Colorado and lived in a privately rented apartment in the City of Denver. ${ }^{21}$ For purposes of local income taxation it seems clear enough that, apart from any express exemption for servicemen, a person on active duty in State $B$, whose permanent residence is in State $A$, is subject to local income taxation at the place of his permanent residence in State $A$. The Soldiers and Sailors Civil Relief Act expressly provides that compensation for military service shall not be deemed income earned within State $B$. This provision is much easier to support than the one as to personal property because it relates to compensation received from the government for military service.

In Ohio there is a problem of appropriate credit for taxes paid one local unit in horizontal juxtaposition to another income tax levying unit. The matter is not regulated by statute and the municipalities have had to chart their own courses. The original Dayton ordinance allowed credit to residents for taxes paid to any other city on income subject to the Dayton tax, but only to the extent of the Dayton tax attributable to that income. ${ }^{22}$ It is not believed that this type of provision would be liable to attack on equal protection grounds, since it is a rational effort to avoid double taxation.

Reference has already been made to the Philadelphia situation. Other Pennsylvania local units with authority to levy income taxes have both a vertical and a horizontal credit problem. In the horizontal situation the unit of residence is favored. The enabling act requires that an income tax paid to a unit of residence shall be credited against such a tax imposed by any other local unit under the statute. ${ }^{23}$

20. 56 Stat. 777 (1942), as amended 58 STAт. 722 (1944), 50 U.S.C. App. $\$ 574$ (1946).

21. Dameron v. Brodhead, 345 U.S. 322 (1953).

22. See Fordham \& Mallison, supra note 1, at 257.

23. Pa. Stat. Ann. tit. 53, $\$ 2015.5$ (Purdon Supp. 1952). 
Since school districts are denied authority to tax the income of nonresidents, they are not directly affected by the credit provision.

In the case of overlapping units the Pennsylvania statute permits a division, by agreement, of the available maximum levy of one per cent. In the absence of such an agreement the act ordains that the levy of each unit shall be one-half of the maximum. ${ }^{24}$ The division of the available taxing power is made automatically by the statute. One notes that this does not take into account the possibility that the levies of two overlapping units might aggregate less than the maximum.

A Pennsylvania city, let us assume, levies a one per cent income tax and the overlapping school district levies a one-half of one per cent income tax. Whichever is levied first, the upshot, as to residents, will be that the effective school district rate will be one-half of one per cent and the effective city rate will be one-half of one per cent. Is this the case with nonresidents who are not taxable by the school district? May the city apply the one per cent rate to their income earned in the city? The Pennsylvania Supreme Court has answered this question in the affirmative. ${ }^{25}$ The court concluded that the allowance of the credit in the vertical situation was, in substance, the same as such an allowance in the horizontal pattern and found in neither a violation of the constitutional requirement of uniformity. This is a happy example of imaginative handling of a uniformity question.

Since Ohio and Pennsylvania, the two leading local income tax states, are neighbors, there is a practical question as to the allowance of a credit for tax paid to a local unit of another state. This question is bothering some Pennsylvania local units in the general Youngstown vicinity at the present time. In view of the broad position taken by the Pennsylvania Supreme Court in upholding the credit device under the Home Rule Tax Act, it is believed that a statutory provision extending the device to the interstate situation would be valid. ${ }^{26}$ It is to be borne in mind, however, that the provision in the Home Rule Tax Act authorizing credits is confined to Pennsylvania local units.

\section{Graduation of Rates}

Nowhere is the rigidity of Pennsylvania's requirement of uniformity of taxation ${ }^{27}$ more conspicuous than with respect to gradua-

24. PA. Stat. Ann. tit. 53, §2015.1(E) (Purdon Supp. 1952).

25. Minich v. Sharon City, 366 Pa. 267, 77 A.2d 347 (1951), appeal dismissed, 341 U.S. 945 (1951).

26. In the Sharon case the court relied on federal cases upholding credits against federal taxes for state taxes paid and declared broadly: "Allowing a credit against the payment of a tax for taxes paid to some other governmental authority is not a violation of the constitutional requirement of uniformity." Minich $v$. Sharon City, 366 Pa. 267, 270, 77 A.2d 347, 348 (1951).

27. PA. CoNST. Art. IX, §1. 
tion of rates. As the clause is interpreted, there can be no more progression in income tax rates than in the rates of ad valorem taxation. Nor may any form of personal exemption be granted, ${ }^{28}$ even though, as observed in a recent Ohio case, the burden of collecting the tax on a very small income may vitiate the revenue potential. ${ }^{29}$ Thus, it would not be possible for Pennsylvania local units to follow the example of certain Ohio cities and exempt outright the earnings of minors under a certain age. ${ }^{30}$

In Ohio the primary legal limitation is an equal protection clause. ${ }^{31}$ The case just adverted to involved a provision of a City of Springfield income tax ordinance which, in effect, exempted from the tax all persons with earned incomes of $\$ 1,040$ per year or less and made the entire earned income of persons whose incomes were more than $\$ 1,040$ per year subject to the tax. In view of the factors of hardship and administrative burden the classification was sustained. From the standpoint of uniformity a pattern of personal exemption which applied alike to all taxpayers would obviously be more acceptable.

\section{INTERGOVERNMENTAL RELATIONS-WITH HOLDING}

The city of Louisville, Kentucky, imposes an "occupational license tax," the measure of which is earned gross income. In 1948 the levy was upheld as an occupational license tax as distinguished from a true income tax. The commonwealth had an income tax; the theory embraced by the court enabled it to avoid preëmption difficulties. In 1950 the city annexed an area which included a federal ordnance plant. The tract had been acquired by the government through condemnation. Exclusive jurisdiction was obtained. In a test case the Kentucky Court of Appeals held that the city could collect the tax from federal personnel working at the ordnance plant. ${ }^{32}$

By an act of 1940 Congress consented to the levy and collection of state and local income taxes in any federal area in the taxing unit. ${ }^{33}$ As defined in the act, an "income tax" is a "tax levied on, with respect to, or measured by, net income, gross income or gross receipts." 34 Since this definition is broad enough to comprehend a levy measured by gross earnings, the Kentucky court found the Louisville impost

28. Butcher v. City of Philadelphia, $333 \mathrm{~Pa} .497,6$ A.2d 298 (1938).

29. City of Springfield v. Kenney, 62 Ohio L. Abs. 123, 104 N.E.2d 65 (Ohio App. 1951).

30. See Fordham \& Mallison, supra note 1, at 253.

31. Oнто Const. Art. I, §2.

32. Commissioners of Sinking Fund of Louisville v. Howard, 248 S.W.2d 340 (Ky. 1952), aff'd, 344 U.S. 624 (1953).

33. 61 Stat. 641 (1947), 4 U.S.C. \$106 (Supp. 1952).

34. 61 Stat. 641 (1947), 4 U.S.C. \$110(c) (Supp. 1952). 
to be an "income tax" within the meaning of the federal statute. The United States Supreme Court agreed. ${ }^{35}$

The fact that a federal area was involved did not bar annexation. Such an area is not an island surrounded by a state; it is in the state and so long as the state does not interfere with the exercise of federal jurisdiction in the federal area it is free to change its geographical configuration of local government as by having the territory annexed to a city. On this conclusion, too, the state and federal courts agreed in the Louisville case.

Withholding is an administrative device of great practical importance to local units which have resorted to income taxation. It is the taxing unit's most effective answer to the problem of collecting from the great body of wage and salary earners. Its justification on a broader basis is a debated matter of policy, which deserves more independent consideration than it can be accorded here.

The immediate concern is with the availability of the device where the employer is another government. State and local units are, of course, required by the Internal Revenue Code to withhold and the power of Congress in the premises has not been questioned. It has been assumed by most of us that a state or local unit could not require the federal government to withhold. The basis for this assumption is the supremacy theory. ${ }^{36}$ In July, 1952, a federal statute designed to pave the way for federal withholding as to non-military employees was enacted. $^{37}$ The bill was so drafted as to extend the benefits to local as well as to state income taxes. At the last moment, however, a socalled corrective amendment, which confined federal withholding to state and territorial income taxes, was adopted. The suggestion that to provide for withholding of local income taxes would impose a seriously objectionable burden on federal departments and agencies must be thoroughly uncongenial to local officials. Over 100,000 local units withhold for "Uncle Sam." Why should he not do as much for a meagre fraction of that number of the local units?

The Supreme Court of Pennsylvania has in substance confirmed what was said in the earlier paper as to withholding by the state or other local units. If not authorized by statute the levying unit can(1953).

35. Howard v. Commissioners of Sinking Fund of Louisville, 344 U.S. 624

36. But see Roberts, "Pay-as-Yon-Go" Withholding Under State and Local Income Tax Lazes, 5 NAr. TAX J. 335, 341 (1952). Mr. Roberts is not satisfied that federal immunity carries this far; there are no federal cases directly in point. Now that Congress, as appears in the text at note 37 infra, has consented to withholding in the case of a state or territorial income tax, are we not to say that the intent is to deny withholding as to local income taxes in any event.

37. Pub. L. No. 587, 82d Congi, 2d Sess. (July 17, 1952). 
not compel withholding. The court has held that, absent such authority, a borough could not require a school district to collect an admission $\operatorname{tax}^{38}$

\section{ConCluston}

A brief, largely expository paper might well be brought to a close without a formal "conclusion." In this instance the opportunity will be seized to make one policy observation. The time indeed has come for a thorough study of tax policy and fiscal relations in this country on an adequate scale. Local income taxation, for example, can be adequately evaluated only in the larger perspective. It is most heartening that opportunity now affords. Congress has passed, with administration endorsement, a measure which provides for a national commission on intergovernmental relations in fiscal and other matters. ${ }^{39}$ This is a great challenge. If it is properly met we shall be much better armed to meet soundly the fiscal problems of all levels of government.

38. Wilkinsburg Borough v. Wilkinsburg Borough School District, 365 Pa. 254, 74 A.2d 138 (1950).

39. S. 1514, passed June 4, 1953, 99 Cong. Rec. 6309. 